\section{FRAUD FOLLOWS THE FUNDS}

The best-endowed research centers also report the most cases of fraud, according to data from the US Office of Research Integrity. In the US, the 75 wealthiest schools-which account for little more than $3 \%$ of the 2,290 research centers included-reported nearly $60 \%$ of suspected misconduct cases between 1992 and 2001 .

Misconduct data from ten top-funded NIH grantees, 1992-2001 and 2001 to date

\begin{tabular}{|c|c|c|c|c|}
\hline NAME & $\begin{array}{c}2004 \text { NIH } \\
\text { funding (US\$) }\end{array}$ & $\begin{array}{l}\text { Reported potential } \\
\text { misconduct }\end{array}$ & $\begin{array}{l}\text { Finding of } \\
\text { misconduct }\end{array}$ & $\begin{array}{l}\text { Finding of misconduct } \\
2001 \text { to date }\end{array}$ \\
\hline U Pittsburgh & $360,635,035$ & 20 & 4 & 1 \\
\hline Johns Hopkins & $599,151,309$ & 15 & 2 & 0 \\
\hline Harvard & $325,665,202$ & 14 & 4 & 1 \\
\hline Yale & $323,614,091$ & 9 & 1 & 0 \\
\hline U Washington & $473,432,138$ & 8 & 1 & 0 \\
\hline UCSF & $438,778,831$ & 7 & 4 & 1 \\
\hline U Penn & $464,076,925$ & 7 & 2 & 0 \\
\hline U Michigan & $368,176,446$ & 6 & 2 & 1 \\
\hline Washington U & $388,307,875$ & 5 & 1 & 1 \\
\hline UCLA & $361,593,433$ & 4 & 0 & 1 \\
\hline
\end{tabular}

\section{Catching the crooks}

\section{을 Governments, universities and journals all have roles to play in dealing with fraud, says Emma Marris.}

Scientists abhor meddling. They have for the most part convinced governments that they can and should regulate themselves. Academic standards should in theory be the same worldwide, but cultural attitudes often play a role. The European Science Foundation and the US Office of Research Integrity are planning a conference to discuss harmonizing policies, but in the meantime there are sharp differences in the ways different governments deal with allegations of fraud.

On 12 April, the $\boldsymbol{U} K$ launched a Research Integrity Office, a decade in the making, to advise scientists on a code of good practices.

In the US, the Office of Research Integrity oversees university investigations of research funded by the Public Heath Service, which includes the National Institutes of Health, the Centers for Disease Control and Prevention and a number of smaller agencies.

Denmark has a strong centralized system with a national Committee on Scientific Dishonesty that investigates allegations of misconduct in all research. Other countries have proposed similar agencies.

In Japan, for example, the government has promised to look into misconduct after a recent case exposed uncertainty over universities' legal authority in such matters (Nature 439, 514; 2006).

And a recent fraud case in Norway has given wings to efforts to make research fraud illegal and to set up a misconduct board based on the Danish model (Nature 439, 248-249; 2006).

\section{Academic answers}

Having the research community police itself might seem risky but, like peer review, it works "spectacularly well," says Keith Yamamoto, executive vice dean for the school of medicine at the University of California, San Francisco. "Our entire endeavor involves this intrinsic conflict of interest," Yamamoto says. "We ask people to be judged by people who are acting in some cases almost against their self-interest."
In most countries, the university that employs the scientist investigates allegations of misconduct. Following several high-profile cases, many US universities are holding workshops to educate scientists on responsible conduct of research. But there are no data to support the notion that these measures decrease misconduct.

About one-half of fraud allegations turn out to be real. "Sometimes in the 50\% that aren't misconduct, there are issues like poor mentorship, sloppiness or poor record-keeping," says Margaret Dale, dean of faculty and research integrity at Harvard University.

\section{Stop the presses}

After each misconduct case breaks, journal editors typically spend some time insisting that catching fraud is not their job. Editors have traditionally only informed institutions when they are suspicious about a manuscript. But advances in digital manipulations, and some high-profile cases of fraud, have brought on a few other practices:

- Digital image screening, pioneered primarily at the Journal of Cell Biology.

- The British Medical Journal and others send select papers to statisticians for reanalysis. The Journal of the American Medical Association requires industry-sponsored studies to hire an outside statistician.

- Computer scanning to detect plagiarism.

- Required descriptions of who did what in the study.

- Signed statements that the work is genuine.

- Clear misconduct policies in the instructions for authors.

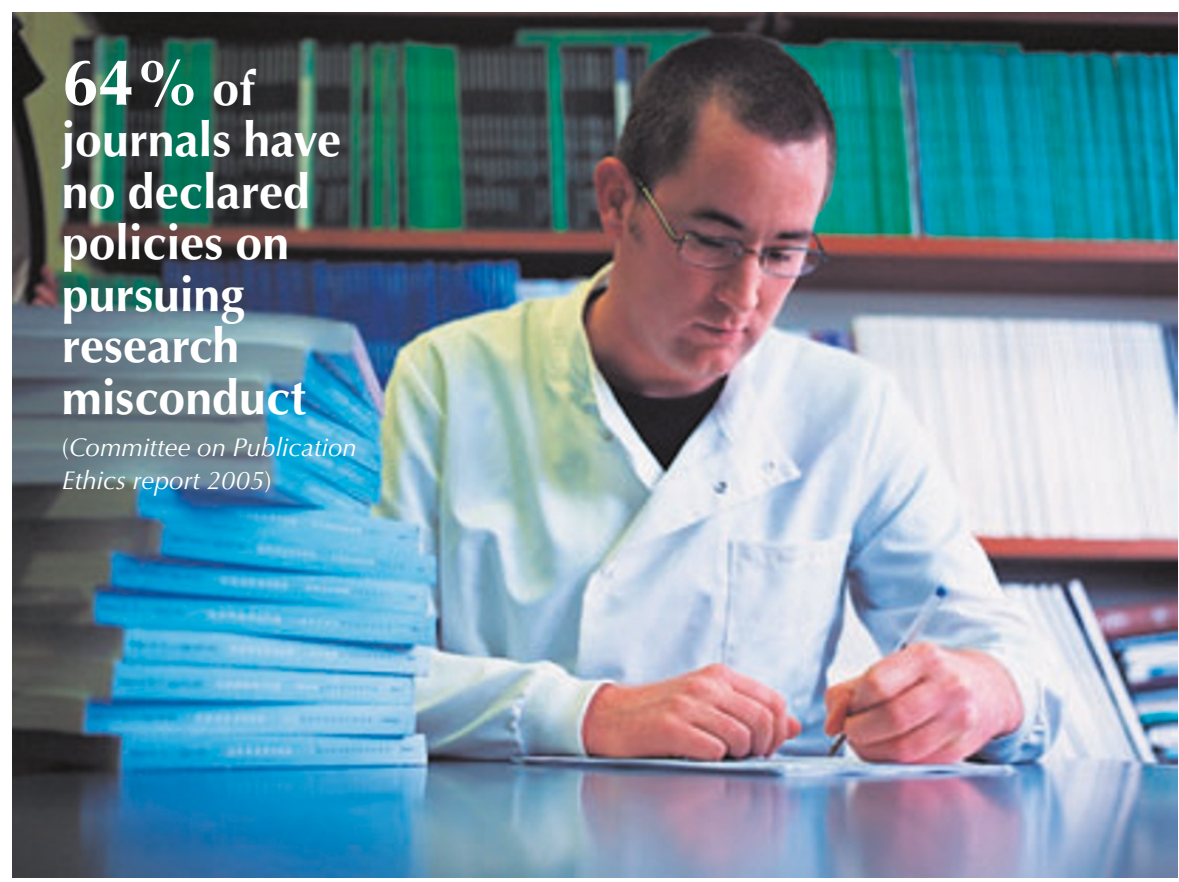

